\title{
MODIS EVI/NDVI alapú monitoring erdôterületeken 2000-2017 között a klímaváltozás földrajzi hatásának kimutatásában
}

\author{
Kovács Ferenc - Gulácsi András
}

DOI: https://doi.org/10.30921/GK.70.2018.5.3

\section{Bevezetés}

A klímaváltozási hatások, területhasználati változások földrajzi kérdései is közrejátszanak abban, hogy a környezeti monitoring rendszerek egyre nagyobb tér-, idô- és spektrális felbontásra törekszenek. Az Alföldön regisztrált klímaváltozás nem átmeneti jelenség és a biomassza-produkció, mint a folyamatosan változó környezeti kondíciók funkciója még nem teljesen ismert, alátámasztott. A vegetáció klímaindikátor szerepe kiemelhetô, változása visszahat az éghajlatra, szélsőségek és trendek jelzôje, aminek távérzékelési megfigyelési módszertana hazánkban is alkalmazható. A trendszerú folyamatok mellett a számítások az éghajlati szélsôségek növekedését is előrevetítik, ezért indokolt a melegedés folyamatának, az aszályok kialakulásának és hatásának nagy idôfelbontású, regionális/lokális vizsgálata. A tanulmány célja, hogy a klímaváltozás ismeretében megfigyelje és értékelje az egyik fố tájalkotó tényezôt, a vegetációt, azon belül is az erdôket érintố következményeket. A vegetáció változása indikátor, ami a klíma alakulását összekapcsolja a tájjal (Farkas et al. 2015), és a monitoring eszköz a változási küszöbérték meghatározásához. Ez hasznos, mert az extrém idôjárási helyzetekkel sújtott területen a heterogén klímakondíciók mellett a felszínfedettség is heterogén. A földhasználatban a 26\%-os erdősültség elérése érdekében 35 év alatt 600-750 ezer ha erdôsítés várható (Nemzeti Vidékstratégia 2012-2020), miközben az erdei ökoszisztémák szerint hazánk a klímaváltozás által fokozottan veszélyeztetett régió (Mátyás et al. 2010).

Az erdốk és a klímaváltozás kapcsolatát illetôen a Nemzeti Erdôstratégiában, a Nemzeti Tájstratégiában a klimatikus viszonyoknak megfelelô fafajok felhasználása szerepel és a klímaváltozással kapcsolatosan az erdôkárok mennyiségi növekedése is szóba kerül. A gyakorlatban kell csökkenteni a hatások mértékét, így annak számszerúsítése, területi lehatárolása, tervezésbe való bevonása csak megalapozott tér-és idôbeli értékelésekkel valósítható meg.

\section{A mintaterület \\ lehatárolása és a vizsgálat tárgya}

Síkvidéken a mezőgazdaság, a településhálózat miatt az erdók általában ritkábbak, ezért a klímaváltozás hatása nehezebben felismerhetô, de a Duna-Tisza köze jó mintaterület a fásszárúak magas aránya és az intenzív erdôsítés miatt. A rendelkezésre álló múholdfelvételek alapján a mintaterületi változások földrajzi értékelését az erdôterületek 2000-2017 nyári félévi monitoring vizsgálatával dolgoztuk fel; a 81-288. napok közötti idôt értékeltük. Az általunk felhasznált, 250 m-es térbeli felbontású MODIS-szenzor által adott raszterhálón a CLC (Corine Land Cover) térképek (2000, 2006, 2012) alapján határoltuk le az erdóket. A nagyobb területeket érintô, természeti zavarás - szárazodás - megfigyelésére a kis felbontás alkalmas, a MODIS-szal változást mérố rendszerek foltmérete minimum 15 ha és az 1,5 ha-nál kisebb változás ezeken a felvételeken nem látszódik (Lunetta et al. 2006, Xin et al. 2013).

A lomb-, tûlevelú és elegyes erdôket külön térképezve a legalább 2/3 részben fedett pixeleket figyeltük meg ott, ahol minimum 3 pixel határol le egy foltot. Kijelölt celláink a CLC idôpontok szerint a tényleges

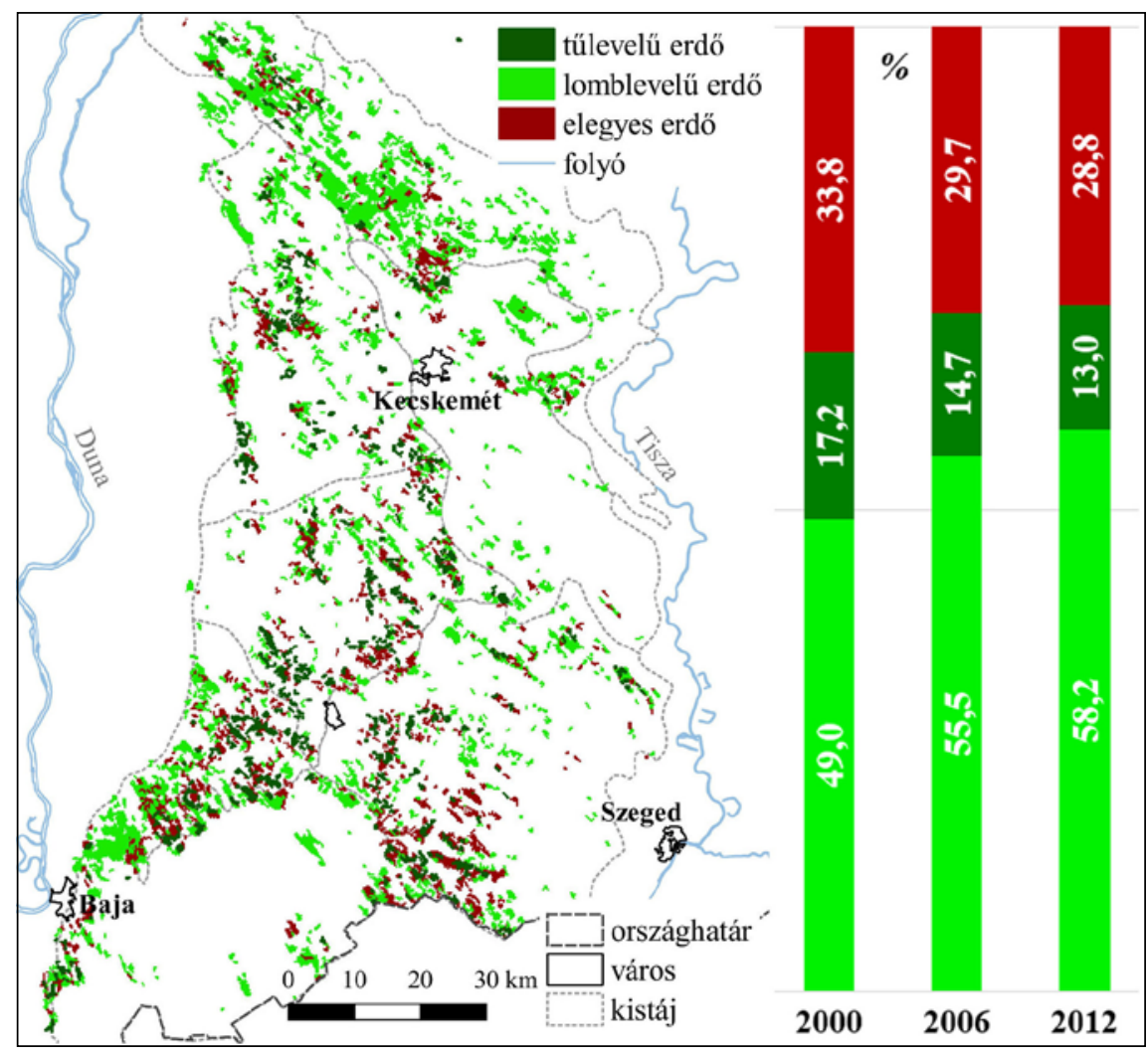

1. ábra. A CLC 2012 alapján vizsgálatba vont erdôterületek és a 2/3 részben fedett erdốs cellák megoszlása a CLC térképezési idôpontokban a mintaterületen 
erdôk 71-85\%-át jelentik (1. ábra). A CLC rétegekben jegyzett változások 2000-2006 között a vizsgált erdôk maximum 1,5\%-át, 2006-2012 között a 7-9\%-át érinthetik. Teszt jelleggel csak az állandó lomblevelú erdóterületeket is vizsgáltuk, amely igazolta, hogy a területi változások nem befolyásolják a teljes adatsor szerinti eredményeket.

\subsection{Környezeti probléma a Duna-Tisza közén: klímaváltozás és az erdó}

A Duna-Tisza közén az utóbbi 30 évben $+1,2-1,5^{\circ} \mathrm{C}$ a melegedés és hússzal-harminccal több nyári nap a jellemzô (Lakatos et al. 2014), amely fokozottabb vízigényt von maga után (Blanka et al. 2014). A szárazodást jellemző „átlag feletti hômérséklet, átlag alatti csapadék" együttes elôfordulásának átlaga a havi adatok alapján a Duna-Tisza közén 2000-2017-ben 40\%; sốt 2000-2003 és 2006.092009.09. között több, mint 60\%. A helyzet súlyosságát az aszályt értékelô Pálfai-féle aszályindex (PaDI) fejezi ki, melynek 1961-1987-es 4,4-5,5es átlaga 1988-2012-ben már 5,6-6,6 (Fiala et al. 2014). A víz funkció változása a talajvíz adatokon trendszerúen mérhetô. A Duna-Tisza közére leírt talajvízhiány az 1960-as évektôl mérve $9 \mathrm{~km}^{3}$ is lehet, amit egy-két csapadékos év középtáji léptékben csak részlegesen tud visszapótolni (Rakonczai - Fehér 2015). A talajvízszint-süllyedésben 13-15\%-ban az erdőterületek és azok növekedése is szerepet játszott (Szilágyi - Vörösmarty 1993, Völgyesi 2006).

A szárazsági határ eltolódásával optimális termóhelyi adottságú helyek kerülnek klimatikus határhelyzetbe, amihez az utóbbi 30 év aszályossága döntően hozzájárult (Móricz et al. 2011). A szignifikáns tavaszi csapadékcsökkenés, az utóbbi évtizedekben egymást követô száraz nyarak hatására Rakonczai et al. (2012) szerint a biomassza-produkció és annak diverzitása is csökken. A Duna-Tisza közi szárazságot erôsíti, hogy az erdôk alatti talajok 98\%-a gyengén víztartó, 2/3-a futóhomok! A klímahatás erôssége, a magassági viszonyok és az esôvíz gyors beszivárgása miatt itt közvetlen a biomassza-csapadék kapcsolat. A Czúcz et al. (2008) szerinti a táji, természeti tôke index a tûlevelú erdôknél átlagosan $7,7 \%$ (max. 32), a lomblevelúeknél 5,8\% (max. 28), elegyes erdóknél 7,1\% (max. 32) (2. ábra).

A fák fenofázis-elcsúszására jellemző, hogy erdeink 20\%-át adó fehér akác virágzása a 90-es évekre már csak május végéig tartott és 19522000 (valamint 1984-1997) alapján 1,9-4,4 nap/dekáddal változott (Varga et al. 2012, Hunkár et al. 2013, Szabó. et al. 2016).

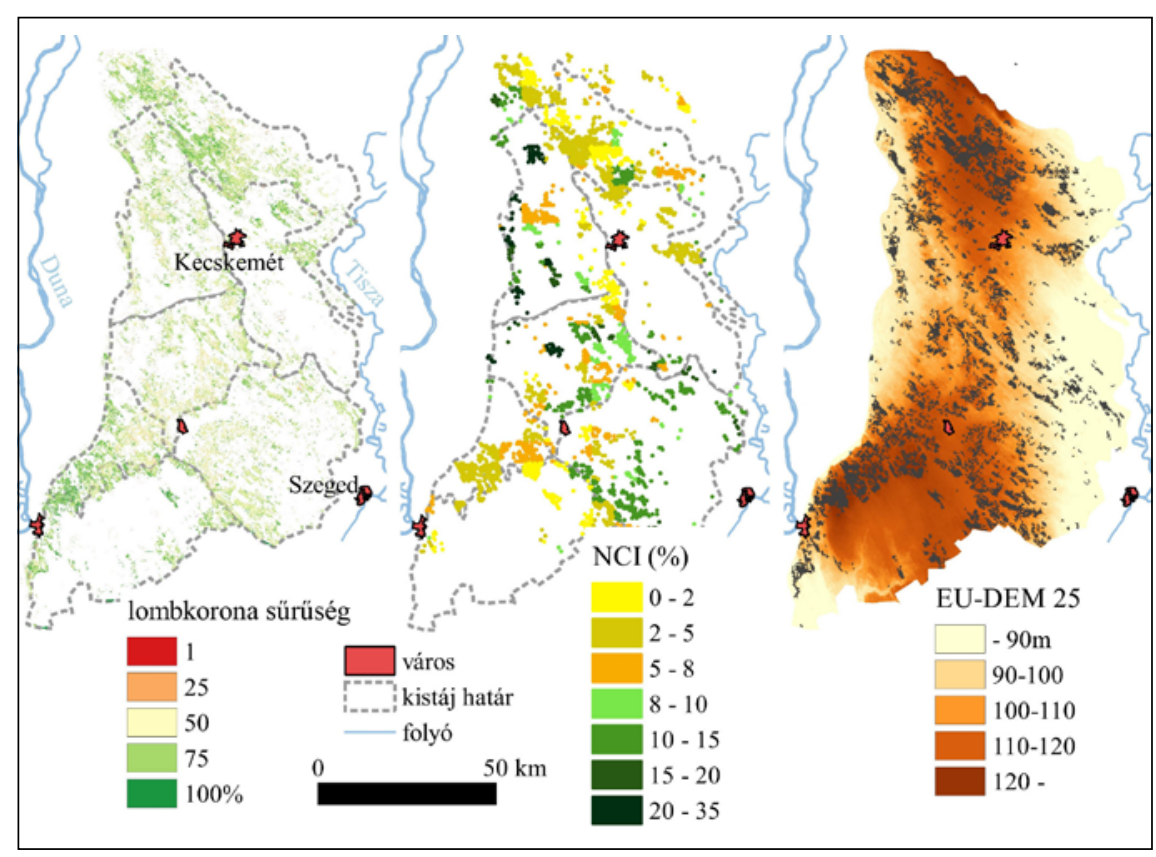

2. ábra. A Duna-Tisza köze erdôterületei (HrL, Czúcz et al. 2008, EU-DEM 25 alapján)

\section{Alkalmazott módszertan}

\subsection{Multispektrális alapadat és termék}

A regionális léptékú megfigyelések fố távérzékelési adata ma a MODIS. A fenológiai folyamatok megkívánnák a két hordozó (Terra, Aqua) együttes használatát, de adott vizsgálathoz általában egyet használnak és a reflektancia korreláció a Terra esetében jobb (Kristóf et al. 2007). A MODIS MVC (Maximum Value Composit) a 8-16 napos periódusokban a cellához az NDVI (Normalized Difference Vegetation Index) maximum érték által prezentált pálya szerinti reflektanciát párosítja. A 8-16 napos periódusok legnagyobb NDVImax értékét és ezáltal a pixel reflektancia értékét az adatminôségi vizsgálat után kapott 5-10 kép közül a kisebb látószögú cella szerint határozzák meg. A kompozit pixeleinek $87 \%$-a a $\pm 30^{\circ}$-os látószögú tartományban van (Solano et al. 2010). Vizsgálatunkban a MOD13Q1, 16 napos, 250 m-es felbontású kompozit termékét használtuk. A képfeldolgozás miatt a kompozit közelebb áll a terepi adatokhoz, mint a napi reflektancia adat (Hmimina et al. 2013).

A pixel alapon elérhetô minôségi adatok (MOD13Q1 QA) szerinti részletes ellenôrzést programozási megoldásokkal hajtottuk végre, amivel országos átlagban $75 \%$ érvényes pixelértéket kaptunk (Kovács et al. 2017). Ha a leválogatott erdôs cellák minimum 80\%-a elemzésre alkalmas, akkor 18 év 468 képi értékbôl álló idôsorának 95\%át értékelhetjük (1. táblázat). A nyári félévet jellemzố 13 kompozitnál 6 darabra jellemzô a hiánytalan adatsor, illetve maximum két rossz idôszak van egy nyári félévben. Az éveket tekintve 11 év adatsora hiánytalan és itt is maximum két rossz idôszak fordul elô egy évben. A 80\%-nál kisebb, de 60\%-nál nagyobb értékú idốpontok képeit korlátozottan vettük figyelembe.

\subsection{NDVI és EVI, mint általánosan használt vegetációs indexek}

A 70 -es évek óta a spektrális vegetációs indexek (VI) biztos értéket adnak a kvantitatív elemzéshez; a vegetációs információ legalább 90\%-a mérhetô 
Kovács Ferenc - Gulácsi András: MODISEVI/NDVI alapú monitoring erdöterületeken...

A MOD13Q1 erdố cellák teljessége (2000-2017)

(szürke cella: adathiányos idô, világoszöld cella: korlátozottan elemezhetố idô,

sötétzöld cella: jó minốségú és elemezhetố idô, fehér cella: tökéletesen elemezhetố idố)

\begin{tabular}{|c|c|c|c|c|c|c|c|c|c|c|c|c|c|}
\hline MOD & 81 & 97 & 113 & 129 & 145 & 161 & 177 & 193 & 209 & 225 & 241 & 257 & 273 \\
\hline 16 nap & $\begin{array}{l}03.22- \\
04.06 \text {. }\end{array}$ & $\begin{array}{l}04.07- \\
04.22 \text {. }\end{array}$ & $\begin{array}{l}04.23- \\
05.08 .\end{array}$ & $\begin{array}{l}05.09- \\
05.24 \text {. }\end{array}$ & $\begin{array}{l}05.25- \\
06.09 \text {. }\end{array}$ & $\begin{array}{l}06.10- \\
06.25 \text {. }\end{array}$ & $\begin{array}{l}06.26- \\
07.11 .\end{array}$ & $\begin{array}{l}07.12- \\
07.27\end{array}$ & $\begin{array}{l}07.28 \\
08.12\end{array}$ & $\begin{array}{l}08.13- \\
08.28\end{array}$ & $\begin{array}{l}08.29 \text { - } \\
09.13 \text {. }\end{array}$ & $\begin{array}{l}09.14- \\
09.29 .\end{array}$ & $\begin{array}{l}09.30- \\
10.15 .\end{array}$ \\
\hline 2001 & $100 \%$ & $>80 \%$ & $100 \%$ & $100 \%$ & $100 \%$ & $>80 \%$ & $100 \%$ & $100 \%$ & $100 \%$ & $100 \%$ & $100 \%$ & $100 \%$ & $100 \%$ \\
\hline 2002 & $100 \%$ & $100 \%$ & $100 \%$ & $100 \%$ & $>80 \%$ & $100 \%$ & $100 \%$ & $100 \%$ & $100 \%$ & $100 \%$ & $100 \%$ & $<80 \%$ & $100 \%$ \\
\hline 2004 & $100 \%$ & $100 \%$ & $100 \%$ & $100 \%$ & $>80 \%$ & $100 \%$ & $100 \%$ & $100 \%$ & $100 \%$ & $100 \%$ & $100 \%$ & $100 \%$ & $100 \%$ \\
\hline 2005 & $100 \%$ & $100 \%$ & $100 \%$ & $100 \%$ & $100 \%$ & $100 \%$ & $100 \%$ & $100 \%$ & $100 \%$ & $100 \%$ & $100 \%$ & $100 \%$ & $100 \%$ \\
\hline 2006 & $100 \%$ & $100 \%$ & $100 \%$ & $100 \%$ & $<80 \%$ & $100 \%$ & $100 \%$ & $100 \%$ & $<80 \%$ & $100 \%$ & $100 \%$ & $100 \%$ & $100 \%$ \\
\hline 2007 & $100 \%$ & $100 \%$ & $100 \%$ & $100 \%$ & $100 \%$ & $100 \%$ & $100 \%$ & $100 \%$ & $100 \%$ & $100 \%$ & $100 \%$ & $100 \%$ & $100 \%$ \\
\hline 2008 & $100 \%$ & $100 \%$ & $<60 \%$ & $100 \%$ & $100 \%$ & $100 \%$ & $100 \%$ & $100 \%$ & $100 \%$ & $100 \%$ & $100 \%$ & $100 \%$ & $100 \%$ \\
\hline 2010 & $100 \%$ & $100 \%$ & $100 \%$ & $<60 \%$ & $100 \%$ & $100 \%$ & $100 \%$ & $100 \%$ & $100 \%$ & $100 \%$ & $<80 \%$ & $100 \%$ & $100 \%$ \\
\hline 2011 & $100 \%$ & $100 \%$ & $100 \%$ & $100 \%$ & $100 \%$ & $100 \%$ & $100 \%$ & $100 \%$ & $100 \%$ & $100 \%$ & $100 \%$ & $100 \%$ & $100 \%$ \\
\hline 2012 & $100 \%$ & $100 \%$ & $100 \%$ & $100 \%$ & $100 \%$ & $100 \%$ & $100 \%$ & $100 \%$ & $100 \%$ & $100 \%$ & $100 \%$ & $100 \%$ & $100 \%$ \\
\hline 2013 & $<60 \%$ & $100 \%$ & $100 \%$ & $100 \%$ & $\sim 60 \%$ & $100 \%$ & $100 \%$ & $100 \%$ & $100 \%$ & $100 \%$ & $100 \%$ & $100 \%$ & $100 \%$ \\
\hline 2014 & $100 \%$ & $100 \%$ & $100 \%$ & $100 \%$ & $100 \%$ & $100 \%$ & $100 \%$ & $100 \%$ & $>80 \%$ & $100 \%$ & $100 \%$ & $100 \%$ & $100 \%$ \\
\hline 2015 & $100 \%$ & $100 \%$ & $100 \%$ & $100 \%$ & $100 \%$ & $100 \%$ & $100 \%$ & $100 \%$ & $100 \%$ & $100 \%$ & $100 \%$ & $100 \%$ & $100 \%$ \\
\hline 2016 & $100 \%$ & $100 \%$ & $100 \%$ & $100 \%$ & $100 \%$ & $100 \%$ & $100 \%$ & $100 \%$ & $100 \%$ & $100 \%$ & $100 \%$ & $100 \%$ & $100 \%$ \\
\hline 2017 & $100 \%$ & $100 \%$ & $<60 \%$ & $100 \%$ & $100 \%$ & $100 \%$ & $100 \%$ & $100 \%$ & $100 \%$ & $100 \%$ & $100 \%$ & $100 \%$ & $100 \%$ \\
\hline
\end{tabular}

így és a megfelelô léptékben, a zavaró hatások ellenére - normalizációval jól leírják a vegetációt, a terepi mérésekkel jól korrelálnak (Bannari et al. 1995, Solano et al. 2010). A VI célja növelni a vegetáció válaszát és minimalizálni a talajvilágosságot, a talajszínt, az atmoszférahatást, az árnyékot és a nedvesség-tartalmat. Empirikusan meghatározott értékhatárok jellemzik. Jó indikátor, igaz a multispektrális alapú táji fenológia más, mint az ökológiában gyakori, egyedi karaktert jellemzô fenológia. A vegetációs karakterrel jellemezhetjük a mezógazdasági aszály szintjét, de kimutathatók közvetett környezeti hatások (erózió) is. A talajvegetáció-atmoszféra rendszer leírására törekedve empirikus úton másmás súlyokkal szorozták meg a sávok reflektancia értékeit; ilyen az elsố generációs Green Vegetation Index, amely a LANDSAT MSS és TM sávjaira is számítható (Bannari et al. 1995). A különbségre alapuló indexek használata nem feltétlenül gond, de a normalizált változatok pontosabbak, operatívan használhatók. A második generációs indexek által figyelembe vett háttérzajok közepes (40-60\%) vegetációnál erôsebbek (Huete et al. 2002). Vegetációmonitoring vizsgálatunkban a MOD13Q1 NDVI és EVI (Enhanced Vegetation Index) értékeket használtuk.

$\mathrm{NDVI}=(\mathrm{NIR}-\mathrm{Red}) /\left(\mathrm{NIR}+\mathrm{C}_{1}\right)$

(Rouse et al. 1974)

$\mathrm{EVI}=\mathrm{G} *(\mathrm{NIR}-\mathrm{Red}) /$

$\left(\mathrm{NIR}+\mathrm{C}_{1}{ }^{*} \mathrm{Red}+\mathrm{C}_{2}{ }^{*}\right.$ Blue $\left.+\mathrm{L}\right)$

(Liu és Huete 1995)

NIR: közeli infravörös-, Red: vörös-, Blue: kék hullámhossz-tartomány, $L=1, C 1=6, C 2=7,5, G=2,5$

Az NDVI index alkalmas az erdôterületek lehatárolására, de a nyári félév kezdetén túl-, a végén pedig alábecsülhet. A sok biomasszával bíró erdôterületeken tendál a telítettség felé (Huete et al. 2002). A lombozat alatti résznek köszönhetően (amely a vizsgált menynyiség $14 \%$-a is lehet) lehetséges a korábbi kizöldülés és ezért stabil a VI maximum lombhullatáskor. Felszíni heterogenitásra mutatott érzékenysége miatt érdemes leválogatni a mintaterület növényzetét. A MODIS-adatoknál elôny a keskenyebb vörös hullámhossztartomány, de az atmoszférikus korrekció hibái a reflektancia 1,5-5\%-át tehetik ki, ami a dús vegetációnál okozhat nagyobb eltérést, míg a kalibráció 1,8\% bizonytalanságot okoz (van Leeuwen et al. 2006). Ahl et al. (2006) +/-0,04-es elfogadható MODIS NDVI hibával is kalkulál, ami a kis értékváltozásokat mutató adatsorban fontos paraméter lehet.

Az AVHRR szenzor NDVI termékének a helyét a MODIS EVI és levélfelületi index (LAI) adatai vették át (Ahl et al. 2006). Az EVI pontos a biomaszsza-produktum értékelésénél, mert a dús vegetációnál az NDVI és a klorofill-tartalom kapcsolata nem lineáris az indexértékek telítôdése miatt. Az EVI magas biomassza esetén is jól használható. A kék hullámhossz-tartományú reflektancia a pixelen belüli részleges felhôborítás és légköri aeroszol-tartalom miatt magasabb lehet és nagyobb aeroszol-koncentráció nagyobb különbséget okoz a sávok között; így ezzel a hullámhosszal javítva az index stabilabb. Pontosabban becsüli a lombozat borítottságát, fajtáját, állapotát (Solano et al. 2010). Az óriási adatbázisban az éves, évszakos változás-változékonyság megkülönböztethetô. Érzékeny az erdôtípusokra; a tûlevelú és a lombos erdó EVI között 1,5-szeres az eltérés. Hangsúlyosabb a csökkenés a levélvesztés idején. Az 500 és 1000 m-es, 16 napos MVC VI a látószög és atmoszféra összetételével kapcsolatos érzékenység figyelembe vételével jól becsül, adatai még a sokkal jobb felbontású légi-felvételezéssel 
is összeegyeztethetôk (Huete et al. 2002). Az EVI simább, szimmetrikusabb évszakos profilú, jobban definiált csúccsal, értéke az NDVI-nél alacsonyabb, ami elôny a telítettség kiküszöbölésében. A kétféle VI erdôknél általában nem korrelál, de mintaterületi értékeink ezt nem igazolják (3. ábra). A telítettségi problémát és az értéktartományt jellemzi, hogy az indexértékek füves-cserjés közötti különbsége - ahol az EVI max $=0,4$ és $\mathrm{NDVI}_{\max }=0,7-$ az erdôknél lecsökken; $\mathrm{EVI}_{\text {max }}=0,8$ és $\mathrm{NDVI}_{\text {max }}=0,9$ (Huete et al. 2002). Az indexek kiegészítik egymást, így eredményesebb a változás-detektálás, a biofizikai paraméterek kinyerése. Az EVI elônyei ellenére (Li et al. 2010) erdôs-cserjés területi vizsgálatának 32 napos MODIS MVC adatsorában például az NDVI volt pontosabb.

A standardizált anomália variabilitása kifejező az évek közötti vizsgálatban. Az eltéréseket pixelenként számoltuk 2000-2017 átlagának és szórásának ismeretében.

$\mathrm{EVI}_{\text {standardizátt }}=\left(\mathrm{EVI}_{\mathrm{i}, \mathrm{j}}-\mathrm{EVI}\right.$ átlag $\left.\mathrm{i}_{\mathrm{i}, \mathrm{j}}\right) / \mathrm{EVI} \mathrm{szórás}_{\mathrm{i}, \mathrm{j}}$

A különbözó területhasználatokon (pl. szántó, rét/legelô, erdô) vizsgált standardizált anomália együtt fut a PaDI értékekkel és az aszályos éveket jellemzô negatív eltéréssel határozza meg a mintaterületen (Ladányi - Blanka 2014). Az 500 m felbontású, 8 napos MVC alapján számolt spektrális indexek közül az NDWI (Normalized Difference Water Index) kapcsolata a legszorosabb a Pálfai-féle aszályindexszel (Gulácsi - Kovács 2018).

Napi mérésú MOD09 NDVI alapján a kizöldülés és a lombozat kiteljesedésének kezdete között 21 nap van, így a 16 napos MVC alul-, illetve felülbecsülheti a fenológiai állapotot (Ahl et al. 2006). Terepi és MODIS NDVI mérések közötti kapcsolat a lomblevelǔeknél a kizöldülés és dúsulás idôpontjaiban szignifikáns (Hmimina et al. 2013). Az index alapú modell inflexiós pontjai kevesebb, mint 1 hét eltéréssel illeszkednek a tavaszi zöldülés és az ôszi sárgulás idôpontjaira. A 16 napos MODIS 1,5-7 napos eltéréssel alkalmas a tavaszi NDVI görbe és az inflexiós pont megadására, mert előfeldolgozásuk megbízhatóbb a napi adatokénál.

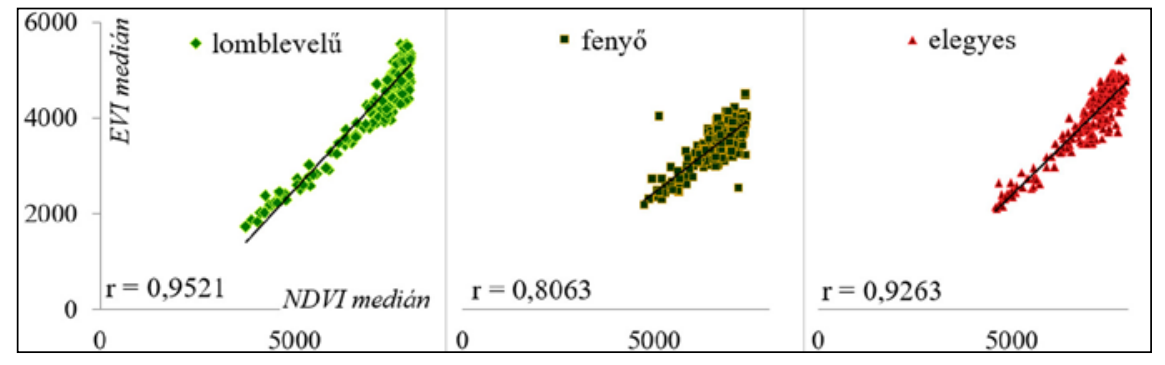

3. ábra. EVI és NDVI értékek kapcsolata a Duna-Tisza köze erdôterületein (2000-2017)

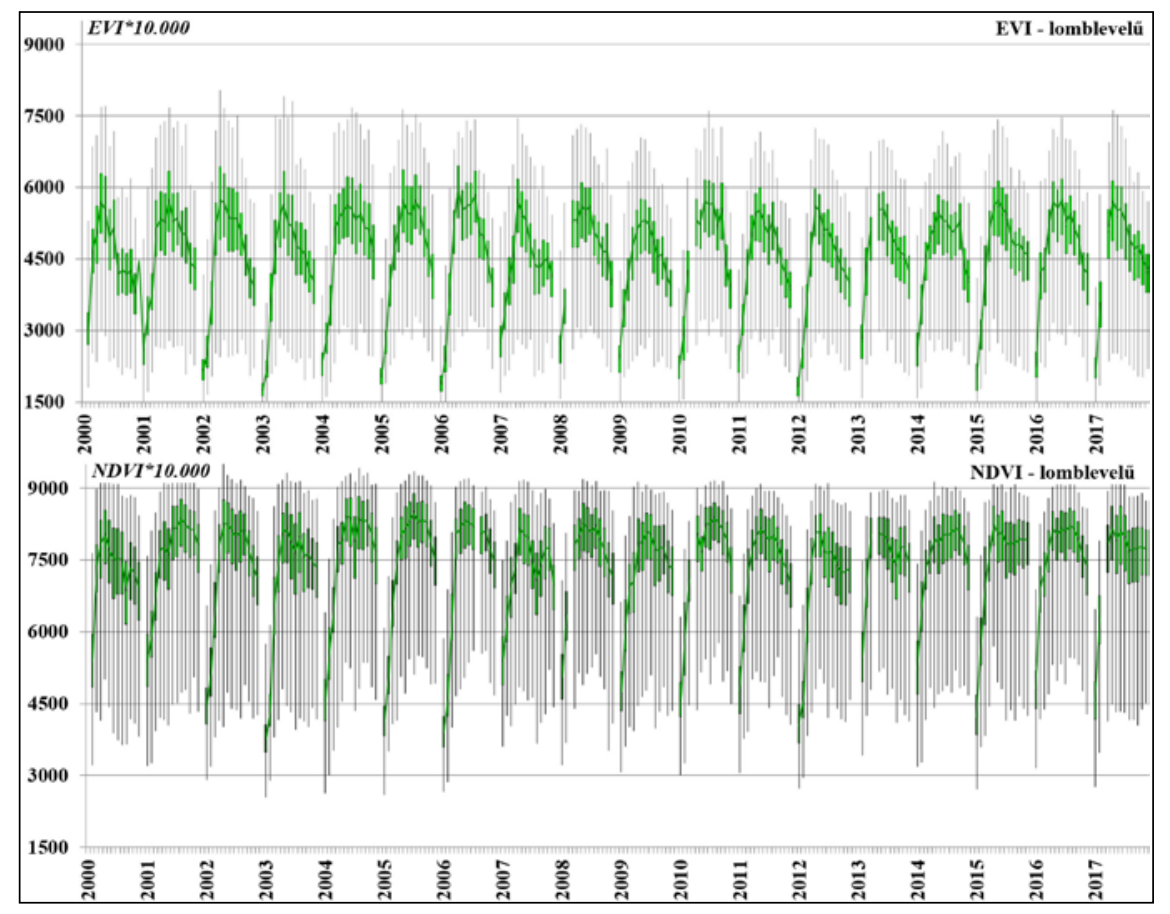

4. ábra. Lomblevelú erdôk EVI/NDVI nyári félév medián értékeinek alakulása (2000-2017)

\section{Erdôs vegetáció \\ értékelése 2000-2017 \\ között a Duna-Tisza közén}

\subsection{A vegetációs index idôsorok jellemzése}

A 2000-2017 közötti EVI adatsor az NDVI indexnél szabályosabb, a külsố hatásokra érzékenyebb képet mutat, az évszakos variációkban feltúnnek a száraz és a vízben gazdagabb idôszakok (4. ábra). A medián értékek jól mutatják az NDVI telítettségi problémát $\left(\mathrm{NDVI}_{\text {lomb }}<0,85 ; \mathrm{EVI}_{\text {lomb }}<0,59\right)$. A lomblevelú és tûlevelú erdố közötti különbség az EVI indexnél általában 25\% feletti, így a különbözó vegetációkat jobban lehatárolja. A mintaterületi szárazodás ellenére a 2000-2017 közötti NDVI és EVI idôsor (medián, minimum, maximum, összeg) nem mutat trendszerú változást, ami annak ellenére is érdekes, hogy tudjuk 18 év kevés a hosszabb távú változások egyértelmú kimutatására. A trend elmaradásában szerepe van a 2013-tól erôsödő biomassza-produkciónak (pedig 2013. és 2015. országosan aszályos évek). 2016 és 2017 általánosan a legmagasabb VI értékú évek!

Az adatok változékonyságát jellemzi, hogy adott hónapokban egy kedvező, esôs év is rendelkezhet alacsony EVI értékkel. A 2010. év például a 18 év legalacsonyabb májusi végi - júniusi EVIlomb értékét adja, ellenben a kedvezótlen, aszályos 2003. és 2012. évek júniusi $\mathrm{EVI}_{\text {lomb }}$ értékei átlag felettiek. $\mathrm{NDVI}_{\text {fenyố }}$ esetében 2001 a legalacsonyabb értékú, míg az NDVI ${ }_{\text {elegyes }}$ ekkor rendelkezik a legmagasabb biomasszaproduktummal és az NDVI ${ }_{\text {lomb }}$ szerint is ez a legjobb évek egyike. Ez a kettôsség jellemzô 2004., 2006., 2009. években is.

A legintenzívebb év közbeni változás a lomblevelú erdők tavaszi növekedése, amikor VI medián értékek május 
elejéig akár +0,16-2,2-vel is nônek egyegy 16 napos idôszak alatt. A kedvezốn növekvô VI értékek egy kevésbé csapadékos - és általánosan melegedô - évben gyorsan lecsökkenek; pl. 2006. utáni 2007. évre. Az egyedülálló nedves évek (2010) magasabb, illetve aszályos évek (2015) alacsonyabb értékei nem kiugróak. 2003 és 2004, illetve 2012 és 2013 összevetésénél látszódik, hogy egy aszályos év alacsony értéke vízutánpótlás esetén gyorsan megnő, ez kb. 8-10\%-os értéknövekedést jelent a lomblevelú erdôk éves biomasszaprodukcióiban. A tûlevelú erdôben a különbség vagy eltolódva tapasztalható, vagy nincs lényeges különbség.

A jelenleg 18 éves idôszakból ki lehet ragadni hosszabb, különbözô irányultságú idôtartamot (ez is jelzi a folyamatos monitoring fontosságát); a biomassza-produktum összeg az erdók 2004-2012. évi idôszakában trendszerűen csökkenô $\left(\mathrm{EVI}_{\text {fenyố }} 2005\right.$-től), de az aktuálisabb 2009-2017 közötti idôben növekvô. A maximum 5, egymást követố szárazabb év csökkenése rendszerint egy csapadékosabb év miatt áll meg, ami elég a fás biomassza produktumnak, hogy hosszabb távon ne gyengüljön. Csökkenési idôsorok EVI/NDVI medián esetében: a rövidebb 2001-2003, a karakteres 20062009 (NDVI $_{\text {lomb }}$ esetében 2005-2009) és a 2010-2014-es idôszak (NDVI szerint inkább 2010-2013).

A lomblevelú erdôk indexértéke a tavaszi idôszakban (03.22-05.08.) a
2000-2006., 2007-2013., 2014-2017. éves csoportokat tekintve összesen 14-25\%-kal is emelkedett (5. ábra). Ez igazolja a melegedés miatt egyre intenzívebb kizöldülést mérố és prognosztizáló elemzéseket (Szabó. et al. 2016). A klimatológia szerinti tavaszi szignifikáns csapadékcsökkenés elemzéseinkben nem látható. Az NDVI ${ }_{\text {lomb }}$ esetében figyelhetôk meg hosszabb, jellemzó csökkenést mutató kritikus idôszakok tavasszal (04.23.-05.08.) 20002006 között illetve a csúcsidôszakban (06.26.-07.11.) 2006-2012 között. A tavaszi intenzitás nô, de a biomasszaprodukció csúcs elérésének ideje 05.25-07.11. között - és a lomblevelú produktivitás mennyisége általánosan nem változik. A csúcsérték nyári eltolódása a fenyô- és elegyes erdôk EVI értékeinél jellemzô; a június eleje 2008-tól a késôbbi júniusi és júliusi idôszakokra tolódik. A 06.10.-07.11-ig terjedô idôszakban a 18 év alatt jellemző a növekedés. A növekvố produkciós értékkel együtt ezeknél az erdôtípusnál gyakoriak a stabil vegetációra utaló másodlagos csúcsértékek, ami nem támasztja alá a fenyôk gyengülésére vonatkozó erdészeti elôrejelzéseket (Mátyás et al. 2010).

Az aszályos 07.12.-09.13. idôszakokban jellemzôk az egymást követô csapadékos/száraz évek közötti - akár 0,8-1,2-es VI medián - különbségek; vagyis a fásszárú vegetáció jól jelzi a környezeti változást; például 2000 és 2001, 2006 és 2007, valamint 2010 és
2011-2012 között. 2007-től a 07.28.08.28. idôszak is kritikus, mert - még az általában jobb VI értékú években is - inkább átlag alatti értékek jellemzik. Szeptember második felében (09.14.09.29.) a lombos és elegyes erdô esetében is csökkenés jellemzó 20042012 között. 09.30.-10.15-ei idôszak $\mathrm{EVI}_{\text {elegyes }}$ emelkedô értékei a növekvô tavaszi értékekkel együtt alátámasztják a teljes vegetációs periódus növekedését, amit Menzel et al. (2006) európai fenológiai megfigyelései során tapasztalt.

\section{2 . EVI átlagtól való eltérésének vizsgálata}

A standardizált EVI pixelenkénti vizsgálata idóben és térben is kijelöli a biomasszamennyiség-csökkenés miatt potenciálisan veszélyeztetett területeket (6. ábra). A tartós eltérések, veszélyeztetettségi szintek a klímaváltozás hatására adott vegetációs válaszok, melyekkel megadható, hogy hol van szükség erdôgazdasági beavatkozásra. A vizsgált 2000-2017 között 7 db átlag alatti év van, így az átlag feletti száma több, de ezen eltérések mértéke például az elegyes erdóknél csekély, illetve térben nem általánosítható.

A standardizált EVI térképek alapján a három legjobb évnek 2004., 2008. és 2016. tekinthetô. Aszályos éveknél feltúnô 2003., 2009. és 2012., amikor az egész mintaterület az átlagtól jelentôsen elmaradó biomassza-produkcióval bír. 2000., 2002., 2007. és 2011.

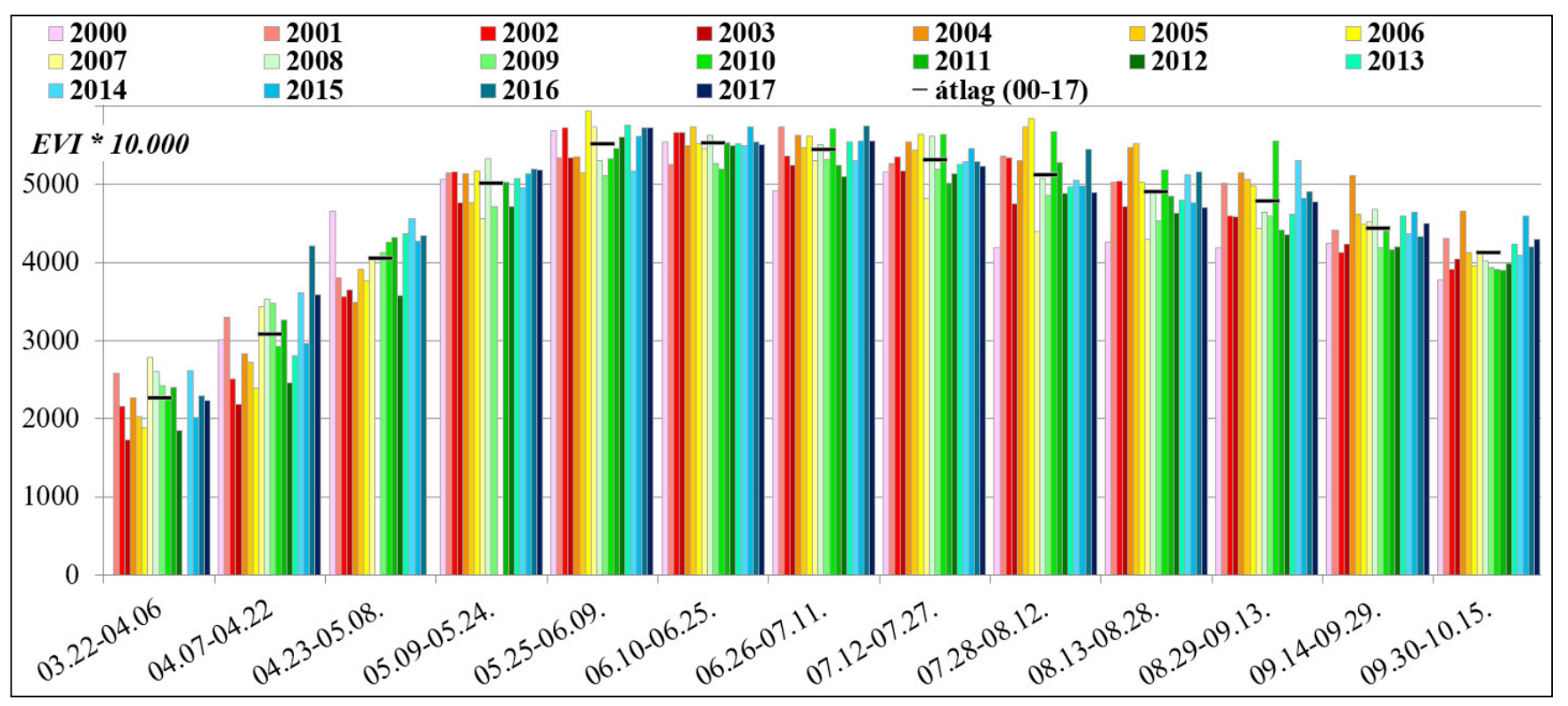

5. ábra. Lomblevelú erdố EVI 16 napos idốszakos medián értékek alakulása (2000-2017) 


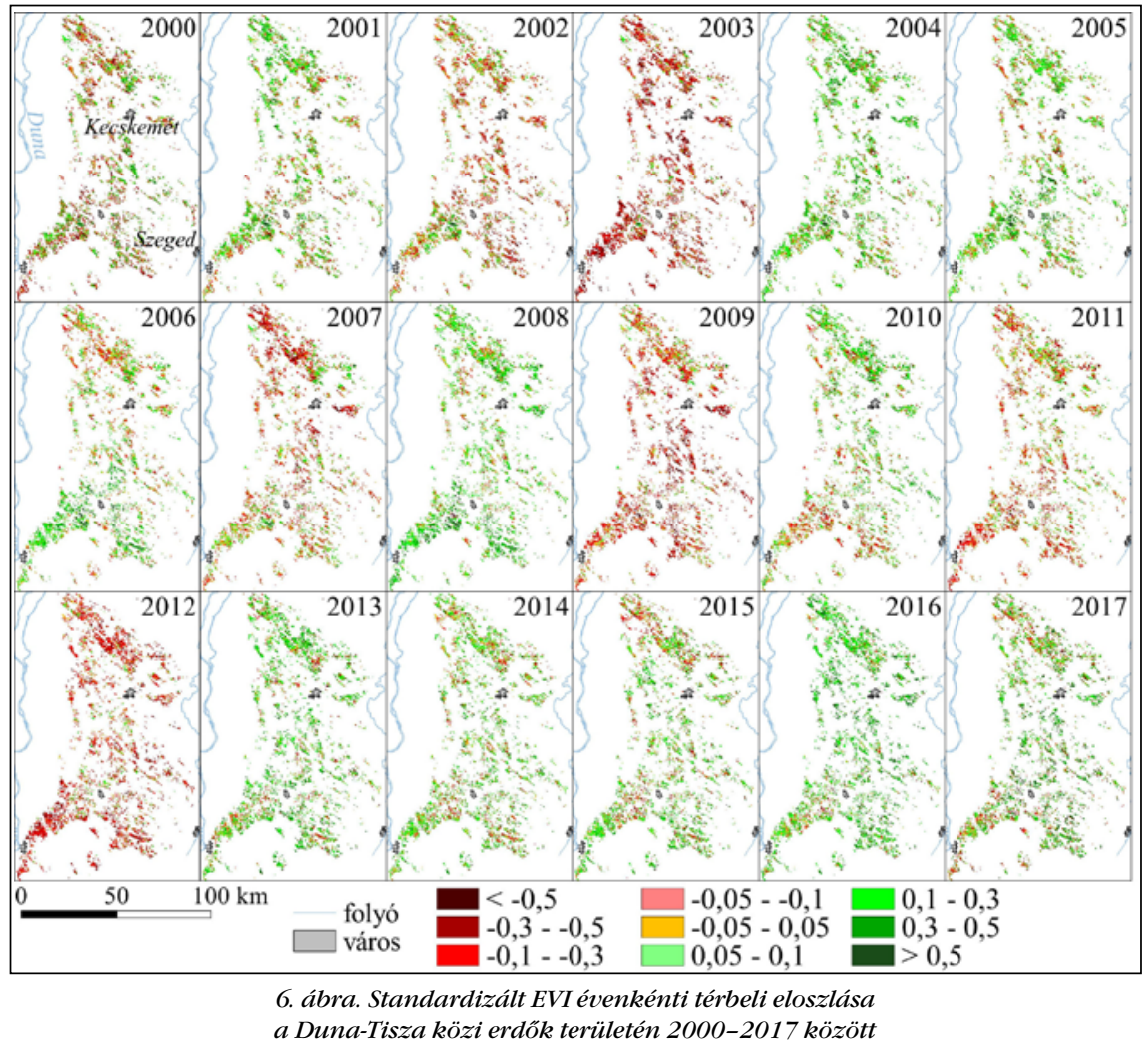

évek is aszályosak, de az előbbi évekhez képest 35-40\%-al kevesebb a negatív eltérés - ami egyben minôsíti az aszályos jelleg extrémitását is - és több az átlagos és a pozitív eltérésú erdô. A térbeliség figyelembe vételével a fentebb jellemzett statisztikai értékelésnél hosszabb negatív trendû idôszakok is kijelölhetốk. A 2007-2012-es negatív idôszak a Duna-Tisza köze déli és fóleg északi területeinek átlagot el nem érő - piros színú - árnyalatait nézve akár 2006-2014/2015-re is bôvíthetô, így a 2013-tól jellemző emelkedő VI értékek a térbeli megoszlás alapján nem vonatkoznak minden területre. Elsôsorban 2014., 2015-ben, de 2017-ben, mint átlagos és pozitív eltérésú években is több, térben koncentráltan megjelenô negatív érték figyelhetô meg, elsôsorban az északi és a déli kistájakon. A 2013. évtôl jellemzố produkció-növekedés (a jelentôs növekedés részaránya a 35-40\%-ot is meghaladja) közben például 2014-2015-ben a fenyôerdők csökkenésének aránya $40 \%$ feletti.

Érdekes, hogy 2010-ben, a legtöbb esôt adó évben jelentôs térbeli különbségek láthatók. Az országos statisztikai adatsor szerint ekkor nem volt aszály, de az erdőknek több mint 30\%-a negatív eltérésú. A legcsapadékosabb évet követô legszárazabb 2011. év jelentôs mértékben visszaveti a zöldtömeget, a lomblevelú 27\%-os negatív eltérése 46\%-ra nô, míg ez az elegyes erdônél 30\%-ról 44\%-ra, a tûlevelû́nél 34\%-ról 66\%-ra emelkedik. A mintaterület déli részén az Illancson és a DorozsmaMajsai-homokháton még 2010-ben is negatív eltérés jellemző, így a területen 2009-2012 között (kisebb foltokon 2013-ig) folyamatosan aszályos körülmények jellemzők. Eltérés-alapú számításaink során több aszályos év hatása nem mutatkozik meg. 2013., 2015. és 2017. egyébként aszályos években láthatók nagyobb negatív eltérésú területek, de 2013-tól a biomassza-produkció pozitív eltérése jellemzô. A 2012. év hasonló mértékú aszálya az eltérés térképen még jól látható, de 2013-ra ez már nem mondható el. A fenyőerdô 40\%-os negatív eltérése kiemelhetô, de aszálynál inkább 70-80\%-os eltéréseket tapasztalunk.

A 2000-2012-es standardizált EVI eltérés adatsor alátámasztja a Kárpátmedencében a közeljövôben fokozódó aszályok földrajzi hatását, de az utóbbi 5 évre ez nem jellemzó (7. ábra). Az aszályos 2003., 2009., 2012. évek és az ezeket követő/megelőzô dúsabb évek - 2004., 2008., 2013. - különbsége szerint aszálykor az átlagosnál gyengébb biomassza-produkció a tûlevelú és elegyes erdôknél 4-szeresére (15-23\%-ról 74-83\%-ra), a lomblevelú erdônél 5-6-szorosára nôhet (12-16\%ról 79-81\%-ra). Látható, hogy az erdőterületek több mint 4/5-e is érintett az aszály által. Még a jelentôsebb eltérést mutató $(-0,1--0,5)$ kategóriánál is jellemzó a 4-5-szörös növekedés; lomblevelúnél 9-10\%-ról 48-56\%-ra. Egy-egy aszályosabb év hatása a fásszárú vegetációnál is gyors és drasztikus következményekkel jár, ami jelentôs erdôgazdasági kockázatot jelent és alátámasztja a megfigyeléseket, melyek szerint a fák is kiszáradhatnak pár hét alatt. Egy, a negatív évet (éveket) követô csapadékos év is gyors és jelentős biomasszaprodukció növekedéssel jár, még akkor is ha több, egymás utáni aszályos évet követ.

A standardizált éves eltéréseket a CLC térképezés szerinti 6 éves időszakokban összegezve (2000-2005, 2006-2011, 2012-2017), a folyamatos eltéréseket vettük figyelembe. A legaktuálisabb térképezési idôszak kedvezőbb biomassza-produktum értékei mellett a lomblevelú 19\%-a, az elegyes erdôk 22\%-a és a fenyők 29\%-a érzékeny a környezeti hatásokra, a klímaváltozásra. A 2000-2005-ös idôszak aszálygyakoriságán keresztül a klímaváltozás jövôbeni hatásaira a lomblevelúek 35\%-a, az elegyes erdók 43\%-a és a fenyôk 39\%-a érzékeny.

Az erdôs vegetációt tekintve a negatív eltérések ismeretében aktuálisan a Pilis-Alpári-homokhát és az Illancs a klímaváltozás szempontjából legveszélyeztetettebb „hot spot” terület. Így erdőgazdasági szempontból északi részen a Csévharaszt-Felsô-Tápióvidéki, a pusztavacsi és a nagykórösi körzetek, míg a déli részen a kiskőrösi, kiskunhalasi, bajai és Alsó-Dunamenti erdôgazdasági körzetek a legérzékenyebbek. A kiskunhalasi, bajai és a Csévharaszt-Felsô-Tápió-vidéki körzeteknél további kockázatot jelentenek a jelentôs területeket elfoglaló tûzveszélyes erdôk. A mintaterületet részletezve a Pilis-Alpári-homokháton a lomblevelúek kedvezôtlen állapota a második térképezési idôben tovább nőtt és a kedvezőbb 2012-2017-ben 100-170 hektáros (elegyes erdônél 


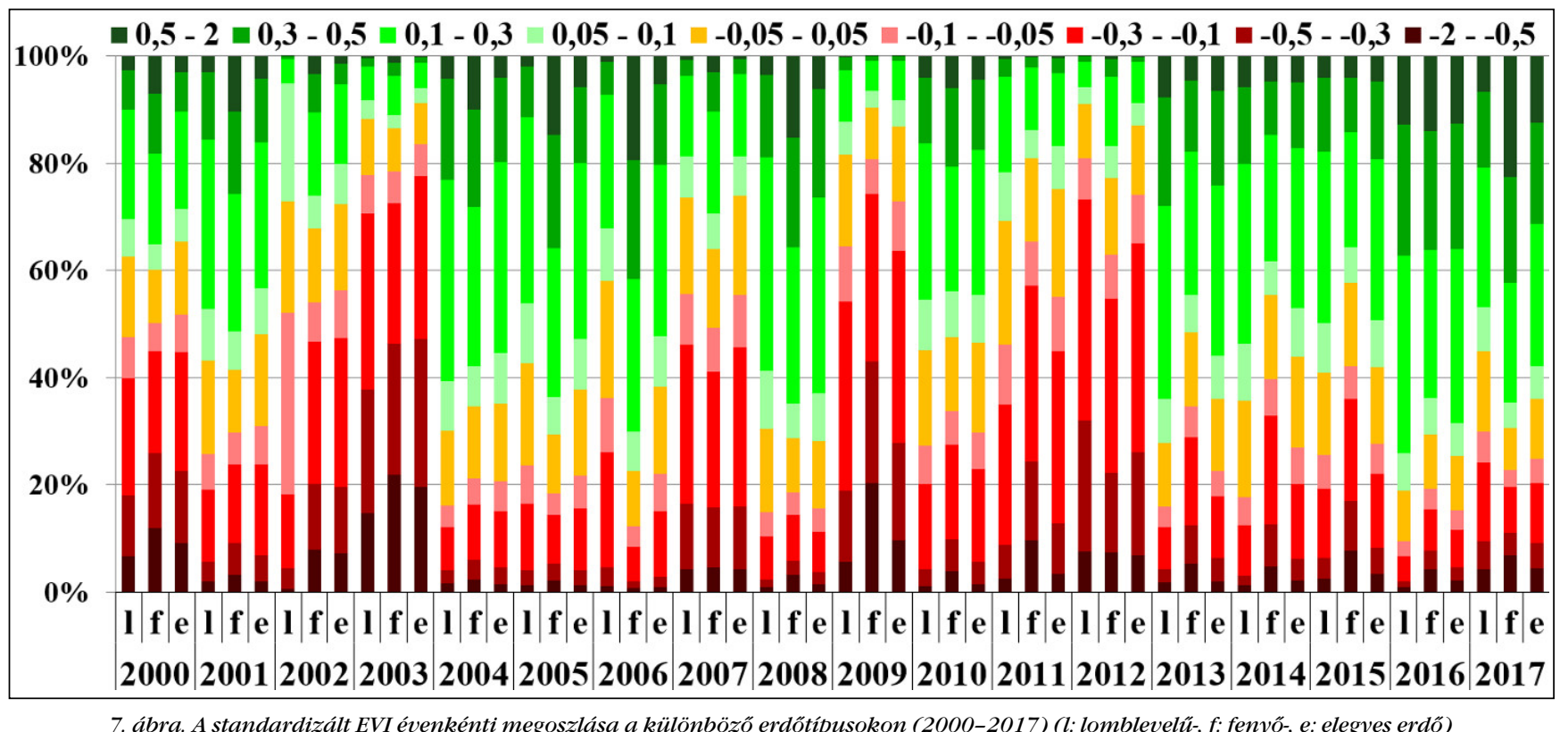

akár 250 hektáros) egybefüggó foltokon vannak jelentős negatív eltérések. Összességében itt van a legtöbb negatív eltérést mutató erdő a mintaterületen a vizsgált idôszakba. Hasonló állapot jellemzi a szomszédos Pesti hordalékkúp-síkságra, Kiskunságilöszöshátra, Kiskunsági-homokhátra átnyúló erdôket. A Kiskunsági- és a Dorozsma-Majsai-homokháton a lomblevelúek biomassza-produktuma aszályos idôszakban szinte a teljes kistájon átlag alatti. Ezen területek a Bugaci-homokháttal együtt a sok kisebb erdőfoltméret miatt érzékenyebbek az aszályokra. Az Illancson a 2006-2011-es időszak után a nagyobb kiterjedésû lomblevelű erdôkön nôtt a negatív eltérés aránya. Az elegyes és a kisebb kiterjedésú túlevelú erdôk aktuális 2012-2017 idôszaki állapota a legaszályosabb 2000-2005 idôszakihoz hasonló. A kistáj területén az általánosan pozitív értékeket mutató 2012 2017 között is nagyon jelentôs negatív eltérés tapasztalható.

\subsection{EVI és NDVI értékek validációja}

Az EVI/NDVI értékeinket a CARPATCLIM adatbázisba készített 10 km-es felbontású, 2000-2010-es idôközre rendelkezésre álló PaDI adatokkal vetettük össze (Szalai et al. 2012). A MODIS alapú erdős pixeleket tartalmazó PaDI cellákra lineáris regressziót, Pearson-féle korrelációt erdôkategóriánként külön számoltunk. A 2. táblázat szoros kapcsolatot mutat a $250 \mathrm{~m}$ felbontású VI értékek és az aszályindex között, de érdekes, hogy a determinációs együttható mindhárom erdôtípusnál az NDVI esetében a magasabb és az elegyes erdőknél a legmagasabb.

NDVI és EVI kapcsolata PaDI értékekkel 2000-2010 éves átlagai alapján 2. táblázat

\begin{tabular}{|c|c|c|}
\hline & $\begin{array}{l}\text { NDVI PaDI } \\
\left(\mathrm{R}^{2}\right)\end{array}$ & $\begin{array}{l}\mathrm{EVI} \sim \mathrm{PaDI} \\
\left(\mathrm{R}^{2}\right)\end{array}$ \\
\hline Lomblevelû́ erdôk & $0,76 * * *$ & $0,72 * * *$ \\
\hline Túlevelú erdôk & $0,74^{* * *}$ & $0,72 * * *$ \\
\hline Elegyes erdôk & $0,85^{* * *}$ & $0,76 * * *$ \\
\hline
\end{tabular}

A különbözó felbontási paraméterekkel, különböző hullámhossz-tartományokban készülố múholdadatok összehasonlításának módszerével is ellenốriztük az eredményeinket. A MODIS EVI és NDVI kompozit értékeket az egyedi időpontokra készült,

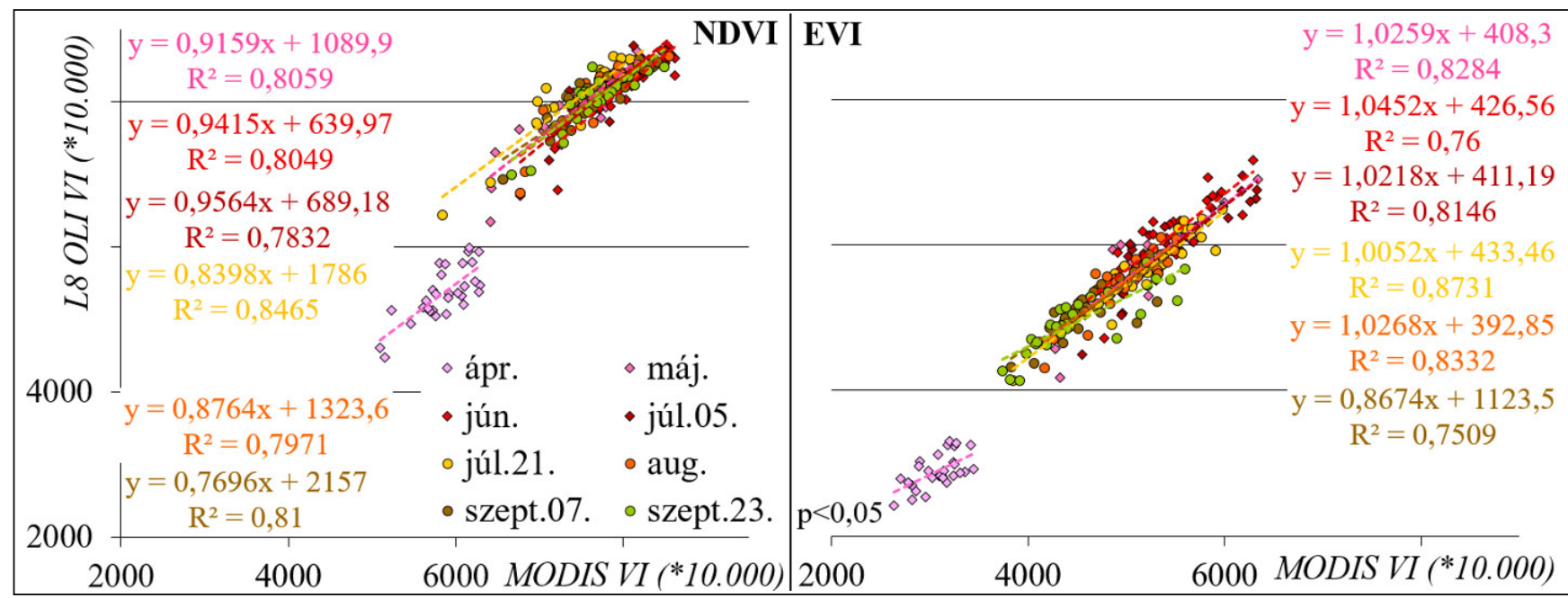

8. ábra. MODIS és OLI NDVI/EVI lomblevelú lineáris regresszió vizsgálat a 2015. évi nyári félévi adatok alapján 
30 m-es felbontású, elófeldolgozott LANDSAT OLI EVI és NDVI mérésekkel vetettük össze 2015. nyári félévének 8 időpontjára. A 30 legnagyobb erdőfoltra vonatkozó értékeket mind a 8 időpontban összehasonlítottuk, ahol a determináltsági koefficiens értéktartományok alapvetôen szoros kapcsolatra utalnak; $0,5546<\mathrm{R}_{\mathrm{EVI}}^{2}<0,8731$ és $0,2593<\mathrm{R}_{\mathrm{NDVI}}^{2}<0,8465$ (8. ábra).

Az idôpontok felében az NDVI, felében az EVI kapcsolat szorosabb. A vegetációs periódusnak megfelelően az áprilisi jól elkülöníthetően a leggyengébb kapcsolat (pl. EVI ${ }_{\text {lomb }}$ szerint $\mathrm{R}^{2}=0,3959$, illetve az NDVI fenyô $_{\text {esetében }} \mathrm{R}^{2}=0,2593$ ). A júliusban tapasztalt igen magas értékek szerint $\left(\mathrm{EVI}_{\mathrm{lomb}}: \mathrm{R}^{2}=0,8731\right)$ az ezen időpont felvételei hasonlíthatók össze a legjobban. Az EVI/NDVI ${ }_{\text {lomb }}$ kapcsolat a többi nyári hónapban is szoros: $0,7214<\mathrm{R}_{\mathrm{NDVI} / \mathrm{EVI}}^{2}<0,8465$. A determinációs együtthatók alapján a megfelelô minőségú, nagy időfelbontású, homogén felszínfedettségú MODIS adatok nagyon jól használhatók a regionális vizsgálatokra. A fenyố esetében a kapcsolat ennél általánosan gyengébb, de a statisztikai kapcsolat a nyári hónapokban, fóleg az EVI indexet tekintve itt is szoros $\left(0,6033<R^{2}<0,7572\right)$. Ez az összehasonlító elemzés az EVI jobb használhatóságát, pontosságát igazolja.

\section{5. Összefoglalás}

Környezeti monitoring vizsgálatunk egyedi jellegét a nagy időfelbontású regionális elemzés adja, amelyet a minél pontosabb, homogénebb felszínfedettségi lehatárolás mellett a legnagyobb térbeli felbontás használatával értük el. Eredményeinket az adatok körültekintố előfeldolgozása is megalapozta. Az előfeldolgozás és elemzés módszertana eredményül szolgál az automatikus változás-érzékeléshez, amely az alkalmazott MODIS adatok esetén közel valós idejú monitoringot, így a gyakorlati alkalmazást is támogatja.

A lomblevelú, elegyes és túlevelú biomassza-produktumra jellemző alapvető különbségek jelzik, hogy a folyamatok csak ebben az egy tájalkotó tényezóben is összetettek. A változékony vegetáció megfigyelésében a háromféle fásszárú vegetációt kétféle vegetációs indexszel vizsgáló elemzés adatai különbözô folyamatokat is mutatnak, a környezeti adatok ismeretében is meglepô értékeket produkálnak. A monitoring folytatásával a hosszabb idôsor segít elkülöníteni a lassabb - klímaváltozás okozta - változásokat, a gyorsabb - erdógazdasági -hatásoktól és pontosítja a változékony vegetáció megfigyelését.

A 2000-2017 közötti teljes vegetációs index adatsorokban az erdô biomassza-produktuma összességében nem mutat trendszerú változást. A klímaváltozás földrajzi hatásaként az extrém vízhiányos éveknek/idôszakoknak az erdôs vegetációban okozott befolyása az eltérések statisztikai és térbeli megjelenésével jól értékelhetô. Ezek gyakoribb előfordulása már rövidebb idősorban is megfigyelhetố biomasszacsökkenést mutat; például 2004-2012 között a lomblevelû́ erdôknél. Jól értékelhetôk a vegetációs periódus egyegy időszakára jellemzố módosulások, mint a tavaszi intenzitás növekedése, vagy a nyári produktum változása.

Az évközi változások a közel két évtizedes idôtávban jelenleg kiegyenlítôdnek és évtizedes léptékben stabil állapotúak, de az erdôk rövid idôtartamon belül sérülékenyek. A változékonyságon látható a vegetáció környezeti hatásokra adott gyors válasza. A klimatológiai elốrejelzések alapján a melegedés folyamata, illetve az extrém száraz, aszályos időszakok előfordulásának gyakorisága a közeljövőben fokozódni fog, ami tartóssá teszi a jelenleg még rövidebb idôszakra jellemzó biomassza-produktum csökkenést.

A folyamatok összetettsége miatt az aridifikációs kutatásokban érdemes törekedni a szintézis alapú gyakorlati javaslatok megfogalmazására, amelyben a vegetációmonitoring használatát már több ingyenes, nagy felbontású távérzékelési adatbázis-szolgáltatás is támogatja. Eredményeink a távérzékelési adatszolgáltatás minôségi javulásának is köszönhetôk.

\section{Köszönetnyilvánítás}

A tanulmány a Bolyai János Kutatási Ösztöndíj támogatásával készült.

A kutatást az Interreg-IPA Magyarország-Szerbia Határon Átnyúló Együttmúködési Program keretében és az Európai Unió társfinanszírozásával (IPA) megvalósuló HUSRB/1602/11/0057 WATERatRISK projekt támogatta.

\section{Irodalomjegyzék:}

Ahl, D.E. - Stith, T.G. - Sean, N.B. - Nikolay, V.S. - Myneni, R.B. - Knyazikhin, Y. 2006. Monitoring spring canopy phenology of a deciduous broadleaf forest using MODIS. Remote Sensing of Environment 104, pp. 88-95. DOI: $10.1016 /$ j.rse.2006.05.003

Bannari, A. - Morin, D. - Bonn, F. - Huete A.R. 1995. A review of vegetation indices Remote Sensing Reviews 13. pp. 95-120. DOI: $\underline{10.1080 / 02757259509532298}$

Blanka, V. - Ladányi, Zs. - Mezôsi, G. 2014. A jövôben várható klímaváltozás a régióban. In Blanka, V. - Ladányi, Zs. (szerk.): Aszály és vízgazdálkodás a Dél-Alföldön és $a$ Vajdaságban. SZTE, Természeti Földrajzi Tanszék Szeged, pp. 142-151.

Czúcz, B., Molnár, Zs., Horváth, F - BottaDukát, Z. 2008. The natural capital index of Hungary. Acta Botanica Hungarica 50 (Suppl.1), pp. 161-177. DOI: 10.1556/ ABot.50.2008.Suppl.8

Farkas, J. - Rakonczai, J. - Hoyk, E. 2015. Környezeti, gazdasági és társadalmi éghajlati sérülékenység: esettanulmány a DélAlföldrôl. Tér és Társadalom 29 (1), pp. 149-174. DOI: $10.17649 /$ tet.29.1.2675

Fiala, K. - Blanka, V. - Ladányi, Zs. - Szilassi, P. - Benyhe, B. - Dragan, D. - Pálfai, I. 2014. Drought severity and its effect on agricultural production in the HungarianSerbian cross-border area. Journal of Environmental Geography 7 (3-4), pp. 43-51. DOI: 10.2478 /jengeo-2014-0011

Gulácsi, A. - Kovács, F. 2018. Drought monitoring of forest vegetation using MODISbased normalized difference drought index in Hungary. Hungarian Geographical Bulettin 67 (1), pp.29-42, DOI: 10.15201/ hungeobull.67.1.3

Hmimina, G. - Dufrêne, E. - Pontailler, J-Y. Delpierre, N. - Aubinet, M. - Caquet, B. De Grandcourt, A. - Burban, B. - Flechard, C. - Granier, A. - Gross, P. - Heinesch, B. Longdoz, B. - Moureaux, C. - Ourcival, J-M. - Rambal, S. - Saint André, L. - Soudani, K 2013. Evaluation of the potential of MODIS satellite data to predict vegetation phenology in different biomes: an investigation using ground-based NDVI measurements. Remote Sensing of Environment 132. pp. 145-158. DOI: $10.1016 /$ i.rse.2013.01.010

Huete, A. - Didan, K. - Miura, T. - Rodriguez, E.P. Gao, X. - Ferreira, L.G. 2002. Overview of the radiometric and biophysical performance of the MODIS vegetation indices. Remote Sensing of Environment 83, pp. 195-213. DOI: $10.1016 / \mathrm{s} 0034-4257(02) 00096-2$

Hunkár, M. - Vincze, E. - Németh, Á. 2013. Tavaszi felmelegedés néhány vadnövény fenológiai reagálásában. Légkör 58 (3), pp. 98-105.

Kovács, F. 2012. A klímaváltozás földrajzi hatásainak értékelése távérzékelési módszerekkel. In.: Nyári, D. (szerk.) Kockázat Konfliktus - Kihívás. SZTE TFGT., Szeged, pp. 444-452.

Kovács, F. - van Leeuwen, B. - Ladányi, Zs. - Rakonczai, J. - Gulácsi, A. 2017. Regionális léptékű aszálymonitoringot 
támogató vegetáció- és talajnedvesség értékelés MODIS adatok alapján. Földrajzi Közlemények 141 (1), pp. 14-29.

Kristóf, D. - Pataki, R. - Neidert, D. - Nagy, Z. - Pintér, K. 2007. Integrating temporal and spectral information from lowresolution MODIS and high-resolution optical satellite images: two Hungarian case studies. Proceedings of SPIE, Vol. 6742 DOI: $10.1117 / 12.739474$

Ladányi, Zs. - Blanka, V. 2014. Az aszály és a biomassza produkció kapcsolata In.: Blanka V. - Ladányi, Zs. (szerk.) Aszály és vízgazdálkodás a Dél-Alföldön és a Vajdaságban. SZTE TFGT, Szeged, pp. 103-110.

Lakatos, M. - Bihari, Z. - Szentimrey, T. 2014. A klímaváltozás magyarországi jelei. Légkör 59 (4), pp. 158-163.

Liu H.Q.; Huete A.R. 1995. A feedback based modification of the NDV I to minimize canopy background and atmospheric noise. IEEE Transactions on Geoscience and Remote Sensing 33, pp.457-465. DOI: $\underline{10.1109 / 36.377946}$

Lunetta, R.S. - Knight, J.F. - Ediriwickrema, J. - Lyon, J.G. - Worthy, L.D. 2006. Land-cover change detection using multi-temporal MODIS NDVI data. Remote Sensing of Environment 105 (2), pp. 142-154. DOI: $10.1016 /$ i.rse.2006.06.018

Mátyás, Cs. - Führer, E. - Berki, I. - Csóka, Gy. - Drüszler, Á. - Lakatos, F. - Móricz, N. Rasztovics, E. - Somogyi, Z. - Veperdi, G. Vig, P. - Gálos, B. 2010. Erdôkk a szárazsági határon. Klíma-21 Füzetek, 61. pp. 84-97.

Menzel, A. - Sparks, T.H. - Estrella, N. - Koch, E. - Aasa, A. - Ahas, R. - Alm-Kübler, K. Bissolli, P. - Braslavska, O. - Briede, A. Chmielewski, F-M. - Crepinsek, Z. - Curnel, Y. - Dahl, A. - Defila, C. - Donnelly, A. Filella, Y. - Jatczak, K. - Mage, F. - Mestre, A. - Nordli, O. - Penuelas, J. - Pirinen, P. Remisova, V. - Scheifinger, H. - Striz, M. Susnik, A. - van Vliet, A.J.H. - Wielgolaski, F-E. - Zach, S. - Zust, A. 2006. European phenological response to climate change matches the warming pattern. Global Change Biology 12 (10), pp. 1969-1976. DOI: $10.1111 / \mathrm{j} .1365-2486.2006 .01193 . \mathrm{x}$

Móricz, N. - Berki, I. - Rasztovics, N. 2011. A Nagyalföld erdeinek állapota és hatásuk a talajvízszintre. In. Rakonczai, J. (szerk.) Környezeti változások és az Alföld. Nagyalföld Alapítvány, Békéscsaba. pp. 119-126.

Nemzeti Vidékstratégia 2012-2020. Vidékfejlesztési Minisztérium, p. 126 http://videkstrategia.kormany.hu/ download/4/37/30000/Nemzeti\%20 Vid\%C3\%A9kstrat\%C3\%A9gia.pdf (utolsó letöltés 2018.06.28.)

Rakonczai, J. - Deák J.Á. - Ladányi, Zs. - Fehér, Zs. 2012. A klímaváltozás és tájváltozás kapcsolata alföldi mintaterületeken. In.: Rakonczai, J. - Ladányi, Zs. - Pál-Molnár, E (szerk.) Sokarcú klímaváltozás, GeoLitera, Szeged, pp. 37-62.

Rakonczai, J. - Fehér, Zs. 2015. A klímaváltozás szerepe az Alföld talajvízkészleteinek idôbeli változásaiban. Hidrológiai Közlöny. 95 (1), pp. 1-15.

Rouse, J.W.; Haas, R.H.; Scheel, J.A.; Deering, D.W. 1974. Monitoring Vegetation Systems in the Great Plains with ERTS. In.: Proceedings, 3rd ERTS Symposium 1, pp. 48-62.

Solano, R. - Didan, K. - Jacobson, A. - Huete, A. 2010. MODIS vegetation index user's guide (MOD13 Series) p. 42. https://vip. arizona.edu/documents/MODIS/MODIS VI UsersGuide 01 2012.pdf (utolsó letöltés: 2018.06.28.)

Szabó, B. - Vincze, E. - Czúcz, B. 2016. Flowering phenological changes in relation to climate change in Hungary. International Journal of Biometeorology 60, pp. 13471356. DOI: $10.1007 / \mathrm{s} 00484-015-1128-1$

Szalai, S. - Auer, I. - Hiebl, J. - Milkovich, J. Radim, T. - Stepanek, P. - Zahradnicek, P. - Bihari, Z. - Lakatos, M. - Szentimrey, T. Limanowka, D. - Kilar, P. - Cheval, S. - Deak, Gy. - Mihic, D. - Antolovic, I. - Mihajlovic, V. - Nejedlik, P. - Stastny, P. - Mikulova, K - Nabyvanets, I. - Skyryk, O. - Krakovskaya, S. - Vogt, J. - Antofie, T. - Spinoni, J. 2012. Climate of the Greater Carpathian Region. Final Technical Report.

Szilágyi, J. - Vörösmarty, C. 1993. A Duna-Tisza közi talajvízszint-süllyedések okainak vizsgálata, Vizügyi Közlemények, 75 (3), pp. 280-294.

van Leeuwen, W.J.D. - Orr, B.J. - Marsh, S.E. Herrmann, S.M. 2006. Multi-sensor NDVI data continuity: Uncertainties and implications for vegetation monitoring applications. Remote Sensing of Environment 100, pp. 67-81. DOI: 10.1016/j.rse.2005.10.002

Varga, Z. - Varga-Haszonits, Z. - Enzsölné Gerencsér, E. - Lantos, Zs. - Milics, G. 2012. A fehér akác (Robinia pseudoacacia L.) fejlôdésének bioklimatológiai elemzése. Acta Agronomica Óváriensis 54 (1), pp. 35-52.

Völgyesi, I. 2006. A homokhátság felszínalatti vízháztartása. Vízpótlási és visszatartási lehe tôségek. In XXIV. Országos Vándorgyülés Kiadványa. Pécs. pp. 1-12.

Xin, Q. - Olofsson, P. - Zhu, Z. - Tan, B. Woodcock C.E. 2013. Toward near realtime monitoring of forest disturbance by fusion of MODIS and Landsat data. Remote Sensing of Environment 135, pp. 234-247. DOI: $10.1016 /$ j.rse.2013.04.002

\section{Summary}

Due to the complexity of the climate change induced processes, efforts should be made to formulate practical proposals based on synthesis, in which the use of vegetation monitoring is supported by free remote sensing database services. The forest ecosystem is a particularly important climatic indicator factor. In our study area, Danube-Tisza Interfluve in Hungary the proportion of the forests is high and the afforestation is intense. For the geographic evaluation of climate change, MOD13Q1 NDVI/EVI data in the summer period of 2000-2017 were investigated.

In the whole VI series the biomass does not show any trend change in neither of the forest categories. Reduction in biomass is typical for consecutive drier years, but a subsequent wet season is suifficient for the woody biomass product to avoid a decrease over the longer term. In the main dry periods of July-August, the effect of dry year following the rainy years immediately reduces the green biomass. Based on climate predictions, a permanent decrease rate in biomass is expected in the future. The changes in the vegetation period were also wellassessed in the relatively short 18-year data series, such as a change in spring intensity or an increase in summer biomass product. For example, mixed forests not only shows growth in the sprint, but also at the highest summer values. The deciduous characteristic is the decrease in the maximum biomass production. Currently, the changes over the almost two decades are compensated, but forests are vulnerable within a short period of time. According to the standardized EVI anomalies, in consecutive years with significant biomass differences, production in the north and southwest part of the Danube-Tisza Interfluve was reduced.

The determination coefficients between VI data and CARPATCLIM drought index data show strong relationship $\left(\mathrm{R}^{2} \sim 0,85\right)$. This connection is confirmed by the LANDSAT OLI VI data from 2015 as well.

Kulcsszavak: erdômonitoring, EVI, klímaváltozás, MODIS, NDVI

Keywords: EVI, climate change, forest monitoring, MODIS, NDVI

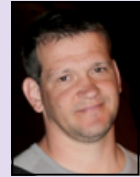

Dr. Kovács
Ferenc
egyetemi
adjunktus

Szegedi Tudományegyetem Természeti Földrajzi és Geoinformatikai Tanszék kovacsf@geo.u-szeged.hu

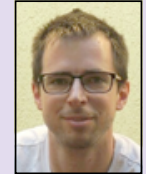

Gulácsi András doktorandusz

Szegedi Tudományegyetem Földtudományi Doktori Iskola guland@protonmail.com 